\title{
Students' Experiences in Using Online Learning Applications Due to COVID-19 in English Classroom
}

\author{
*S Famularsih ${ }^{1}$ \\ ${ }^{1}$ Institute for Research and Community Service, IAIN Salatiga, Salatiga 50716, Indonesia
}

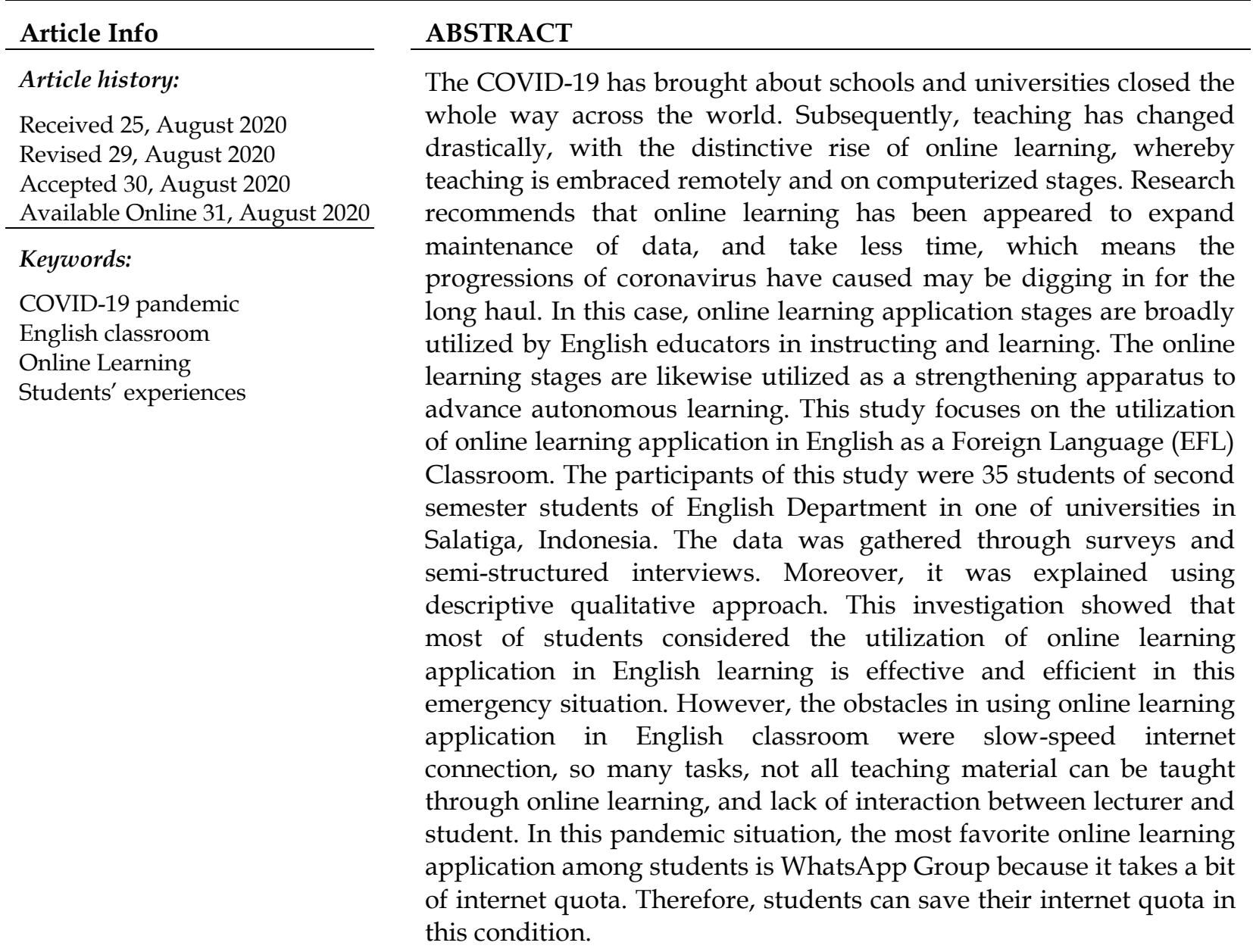

\section{INTRODUCTION}

The COVID-19 pandemic is the first and biggest health crisis in this era. Many countries decide to close schools, colleges and universities. The United Nations (UN) was upset by this fact. International organization headquartered in New York, USA, proves that education is one of the sectors so affected by the corona virus. Worse yet, it happened in a fast tempo and broad scale. Students are forced to learn from home because face-to-face learning is eliminated to prevent COVID-19 transmissions. Moreover, many teachers and lecturers are not yet proficient in teaching using online learning applications, especially in various regions. In some research showed that most of the students had negative perceptions to online learning. However, they agreed that online learning was the right solution during COVID-19 pandemic situation (Rohman et al., 2020). In this situation, Zoom, Skype, and WebEx as video conferencing platforms are being used heavily as are Learning Management Systems (LMS) like Canvas, 
Edmodo, Schoology, Google Classroom, and the like to be one of online learning applications. According to Zhao (2003) the current literature review has found that there is a lot of research on technology implementation in online education related to cost savings and efficiency, that improving the quality and effectiveness of online education requires a framework that must be applied in schools.

The term of "online learning" is related to the 21st Century Education. European Commission (2001) explains it as the use of new multimedia technologies and the internet to improve the quality of learning by facilitating access to resources and services as well as remote exchanges and collaboration. Nowadays, the terms "21st century education" and "21st century skills" are widely known. The concept of 21st century education suggests lecturer to improve their instruction to ensure their students meet the requirement of 21st century skills. The relevant skill is expected to establish students' ability for competitive career and good life, skills for lifelong learning and creative innovation, and skills for literacy, information, media, and technology (Suherdi, 2012). Orlando and Attard (2015) reported that "teaching with technology is not a one size fits all approach as it depends on the types of technology in use at the time and also the curriculum content being taught".

Furthermore, lecturers should integrate technologies with content and pedagogy in teaching processes. 21st century learning is characterized by student's ability in developing social skills one of it is technological skills to exploit ICT tools appropriately (Hwee et al., 2016). Therefore, lecturers should be able to develop the ability to be more creative in using ology to meet students' learning needs. Teaching and learning processes should not only occur in the classroom but technology can be used by both lecturers and students to facilitate language learning materials. Lectures can ask their students to use their gadget such as smartphones or laptop for doing something useful and meaningful.

In online learning, lecturers need Learning Management System (LMS) as a platform for teaching and learning activities. The use of Learning Management System (LMS) is an online learning activity to facilitate collaborative teaching and learning processes. Blended learning defined above is supported extensively by learning management system (LMS) used interchangeably (Wilen-Daugenti, 2009). LMSs and online learning platforms can be used for K12 and higher education. The best LMS for 2018 are Absorb, Moodle, Canvas, Schoology, Blackboard Learn, Brightspace, Edmodo, Qiuzlet and Google class-room, based on editor's rating, SCORM (technical standard for e-learning soft-ware), Bundled Course Content, Single Sign-On (SSO), E-Commerce, Developer API, Available LTI Support, and Native Web Hosting. Chakraborty and Muyia (2014) revealed several factors that can create interesting learning experiences for online learners namely creating and maintaining a positive learning environment, building learning communities, providing consistent feedback on time, and using the right technology to deliver the right material. By using one of LMS, students do not feel bored online learning activities (Mustafa, 2015). Online learning becomes a trend among higher institutions as an alternative approach in teaching and learning processes. It is a solution to overcome physical distance and bring students closer together by carrying out projects in online learning (Haron et al., 2015). In teaching English, the students have experiences that online learning platforms help them to practice language skills and to acquire new English vocabularies (Cakrawati, 2017).

Another digital platform that can give driving force to advance for online learning is WhatsApp. It is an essentially a correspondence application but shares various highlights with social media applications. The use of social media provides feedback between teachers and students and it makes them communicate more efficiently and effectively (Archambault et al., 2016). WhatsApp is created in 2009 in California, it has gotten well known with 1.5 billion users in 180 nations, which makes it the most used chat application, along with Facebook messenger. It provides text, pictures, audio, video, messages for free, and make calls. Ngalomba (2020) states that WhatsApp is cost-effective and user friendly and has competitive advantage over the other social media. WhatsApp provides a safe application due to the inclusion of end-to-end 
encryption (E2EE) procedure. Moreover, this application can check the messages have been received properly and read by the receiver when the blue marks appear next to the messages. The lecturer can also use WhatsApp for one-on-one text exchanges to address individual students' needs. Moreover, discussions, lecture updates, assignment, and submission deadlines can be communicated via WhatsApp. Students can also contact their lecturer via WhatsApp regardless of time differences, physical distance in office working hours. Therefore, lecturer can give students' individual feedback immediately. Using WhatsApp can improve the learning experience and make it relatively easy for lecturers to make interaction with students at their own convenience. WhatsApp application is a useful learning media for teaching English language. Students have opportunities for practicing English language skills and components for free, more personal and comprehensive relationship between students and teachers, they will be more sociable person (Jasrial, 2018). Furthermore, Ristanti (2020) adds based on the research, WhatsApp is a favorite online application for teaching and learning processes because students are familiar in using this application. WhatsApp provides a number of features with social media applications.

However, according to Purwanto et al., (2020) while some believe that the unplanned and rapid move to online learning with no training, insufficient bandwidth, and little preparation will result in a poor user experience in teaching activities. Gillett-Swan (2017) states that in her paper requires very little technological capacity on behalf of the facilitator, but in developing the sense of community and belonging that may be needed to better facilitate an interactive and engaging online learning activities for students and to reduce the obstacles often felt by students in this quarantined situation. This may encourage students' motivation to participate in this online learning activities. The online learning also gives challenges for many academic staff who increasingly require higher levels of technological competency and proficiency. To solve these challenges in online learning, the institutions need to provide professional development for instructors, trainings for learners, and technical support for content development (Kebritchi et al., 2017). Moreover, some of the student anxieties in online learning could be overcame and benefit the students through the pedagogical methods.

Another idea comes from Purwanto et al. (2020) that the students' implication in using online learning in this pandemic situation is they feel forced to study remotely without adequate facilities and infrastructure at home. This facility is very important for teaching and learning process such as laptops, computers or mobile phones that will make it easier for students to participate and listen to their teachers' explanations in the online teaching and learning process. Butler (2012) states that delivering materials in online learning is limited. It makes students feel bored and lack challenges in teaching and learning processes. Croft et al. (2010) argues the lack of interaction and discussion between students on non-cohort-based courses lessens the richness of the learning experience and omits a significant element of the constructivist approach to learning. Social interaction plays an important role in learning. Interacting with other students or teachers has proven to be quite effective in assisting the students to manage their thoughts, reflect on their understanding, and find gaps in their reasoning (Okita,2012). However, in online learning activities the interactions among lecturer and students can be supported by using emoticons. The use of emoticons is to represent emotional and personality nuances present in face-to-face communication (Dunlap et al., 2016).

In this study, students certainly have their own opinions and experiences of online learning in this COVID-19 pandemic situation. The results of analyzing students' experiences in online learning is known to be suggestions for lecturers and institutions in conducting this online learning activity to keep it running well and optimally. Thus, from that background, the purpose of this study is to investigate the learners' perception on Online Learning in the midst of a COVID-19 pandemic. The purpose of this study is to obtain information about students' experiences in using online learning application due to COVID-19 in English classroom. 


\section{RESEARCH METHOD}

This study applied qualitative method as qualitative research is an inquiry process of understanding based on distinct methodological traditions of inquiry that explore a social or human problem (Creswell, 2012). In qualitative research, statistics are not used to analyze the data; Questionnaire and semi-structured interview were used to collect the data in this study. The questionnaire consists of 15 closed-ended questions using a Four-Likert scale and 1 question for students' polling. The questionnaire was adapted from similar previous studies written by Cakrawati (2017). The questionnaire was created to figure out students' perspectives towards the use of online learning platforms in this pandemic situation. The researcher used content validity as validation and one-shot measurement as reliability of this instrument. Content validity refers to the degree to which an assessment instrument is relevant to, and representative of, the targeted construct it is designed to measure (Michalos, 2014). The interview aimed to gain in-depth explanation and description on the use of online learning platforms at home. Furthermore, the researchers interviewed the students by calling them by using WhatsApp application. The interview involving 15 students showed that they found the obstacles of using online learning applications. The respondents of this study were 35 English department students who took English subject class. Moreover, in this class students were not only learning a certain skill but also the four English skills namely listening, speaking, reading, and writing.

\section{RESULTS AND DISCUSSION}

This part presents the findings related to the research questions on students' experiences in using online learning application due to COVID-19 in enhancing language ability. The discussion is explained through the interpretation of the results shown in the tables elaborated with the findings from the questionnaire and interview.

\section{Students' experiences on the use of online learning application in English classroom in pandemic situation}

In this Table 1 showed that most respondents chose agree (65.5\%) and strongly agree (18.5) that learning materials provided by their lecturer in online learning help them in improving their understanding of the subject. The students also agreed $(S A=13.5 \%$, Agree $=65.5 \%)$ that by using online learning they can submit their assignment easily (Chakraborty \& Muyia, 2014). This is in line with student B (S.B) in her interview:

S.B: Menurut saya, online learning harus lebih ditingkatkan lagi karena gampang. Soalnya saya nggak perlu ngeprint tugas.

(I personally think that online learning should be promoted. It is quite simple. Online learning can be easier because I do not need to print out their assignment.)

Even though there are students who are neutral and disagree with question number 3 which stated whether online learning can motivate them to learn about the lesson. However, the highest percentage still can be seen by the students who chose agree $(42 \%)$ and strongly agree $(14.5 \%)$. 
Table 1. Students' Questionnaire

\begin{tabular}{|c|c|c|c|c|c|}
\hline No & Questions & SA & A & $\mathrm{N}$ & $\mathrm{D}$ \\
\hline 1. & $\begin{array}{l}\text { the learning materials such as videos, } \\
\text { power point files, articles and assignments } \\
\text { posted by my lecturer in online learning } \\
\text { help me to improve my understanding } \\
\text { about the learning material. }\end{array}$ & $18.5 \%$ & $65.5 \%$ & $16.0 \%$ & - \\
\hline 2. & $\begin{array}{l}\text { Online learning is convenient to use } \\
\text { especially in submitting assignments. }\end{array}$ & $13.5 \%$ & $65.5 \%$ & $16.0 \%$ & $5 \%$ \\
\hline 3. & $\begin{array}{l}\text { Online learning activities and discussions } \\
\text { can motivate me to learn more about the } \\
\text { lesson. }\end{array}$ & $14.5 \%$ & $42.0 \%$ & $36.5 \%$ & $7 \%$ \\
\hline
\end{tabular}

The next result is Table.2. It showed that respondents agree (38.5\%) and strongly agree $(25.5 \%)$ with the statement that online learning saves effort and time in learning activities (Zhao,2003). Then, majority of the respondents strongly agree $(69.5 \%)$ and agree $(14 \%)$ that the online learning platforms can help them in practicing their English skills. Furthermore, students mostly agreed (strongly agree $=24.5 \%$, agree $=63 \%$ ) that online learning can help them in learning new English vocabulary (Cakrawati, 2017). The table also showed that there were high gaps between agree and neutral or disagree in question 5 and question 6 . Those gaps mean that students have positive experiences towards the use of online learning in the pandemic situation since it can help them to practice their language skills as well as to acquire new English vocabularies while they cannot conduct face-to-face meeting in the classroom. Because of the students agreed that the use of online learning can save their time and efforts, the data shows that students believed that online learning can increase the effectiveness of learning in this emergency situation (Haron et al., 2015). Nevertheless, student M shared her experiences in the online classroom. It can be described in this transcription:

S.M: Bosen. Karena kurang ada tantangan dari pada di kelas langsung. Soalnya waktunya juga limit. Apalagi, kalau disuruh pakai video conference, Cuma ada waktu 45 menit hanya untuk tutorial penggunaannya.

(I feel bored because it was lack of challenges rather than in the classroom. Online learning has limited duration. Especially when we use free video conference, we just have around 45 minutes and we spend much time just for discussing the tutorial of this video conference application.)

However, most of the respondents (45\%) chose neutral and disagree $(30 \%)$ that online learning can facilitate interaction and communication between lecturer and students. Student $\mathrm{O}$, $\mathrm{I}$, and $\mathrm{F}$ gave the reason for this problem:

S.O: Saya nggak bisa ngobrol dan berinteraksi dengan dosen-dosen dan teman-teman secara langsung. Kadang-kadang, Saya WA tapi lama balasnya. (I can't communicate and interact with my lecturers and my friends directly. Sometimes, I just text them and it takes too long to get their response.)

S.I: pembelajaran di kelas bisa berinteraksi langsung sama dosen-dosen dan teman-teman. Saya bisa nanya langsung dijawab. (face-to-face learning allow me to interact directly with my lecturers and friends. I can ask anything that I do not understand and get the answer directly).

S.F: kalau ngirim WA ke dosen, saya pakai Bahasa formal sama pakai emoticon supaya jelas soalnya kelas online nggak ketemu di kelas. (in texting my lecturers, I used formal language and polite emoticon. This is to avoid misunderstanding). 
Table 2. Students' Questionnaire

\begin{tabular}{clcccc}
\hline No & \multicolumn{1}{c}{ Questions } & SA & $\mathrm{A}$ & $\mathrm{N}$ & $\mathrm{D}$ \\
\hline 4. & $\begin{array}{l}\text { The use of online learning saves effort and } \\
\text { time. }\end{array}$ & $25.5 \%$ & $38.5 \%$ & $31.0 \%$ & $5.0 \%$ \\
5. $\begin{array}{l}\text { The use of online learning helps me } \\
\text { practicing my language skills }\end{array}$ & $14.0 \%$ & $69.5 \%$ & $16.5 \%$ & - \\
6. & $\begin{array}{l}\text { Online learning helps me acquiring new } \\
\text { English vocabulary }\end{array}$ & $24.5 \%$ & $63.0 \%$ & $12.5 \%$ & - \\
7. & $\begin{array}{l}\text { The use of online learning increases the } \\
\text { effectiveness of learning }\end{array}$ & $30 \%$ & $57 \%$ & $13 \%$ & - \\
8nline learning facilitates interaction and \\
$\begin{array}{l}\text { communication between lecturer and } \\
\text { students. }\end{array}$
\end{tabular}

In table 3, The result of question 9 showed that the students (strongly agree $=50 \%$, agree $=$ $35 \%)$ decided to choose online learning instead of face-to-face meeting in this pandemic situation (Rohman et al., 2020). In the question 10, many students thought that online learning is easy to use. It is shown by the high percentage of students choosing disagree (39\%). The last question is one of the problems in using online learning platforms is slow-speed internet on students' mobile or personal computer (Purwanto et al., 2020). The table also showed that there are many students choose strongly agree $(47.5 \%)$ in this question. Moreover, in responding question number 10 and 11, student $C, A$, and $G$ gave their opinions as follows:

S.C.:Saya merasa kesulitan karena tiap dosen ngasih tugasnya banyak banget. (I feel hard to do this activity because my lecturers gave me so many homework assignments).

S. A: Di kampung saya internetnya agak lambat jadi kadang saya harus nyari tempat yang tinggi dulu supaya dapat sinyal. (I have slow-speed internet connection in my hometown. Sometimes, I have to find the higher place to get a good internet connection).

S.G:Saya agak kesulitan karena kurang bisa mengatur waktu karena tugas banyak banget apalagi kalua internetnya lambat nggak bisa ngirim tugas tepat waktu. (I think online learning is hard for me because, I can't manage my time to do so many assignments from my lecturers. Especially when the internet connection is very bad, I can't submit my task on time).

Table 3. Students' Questionnaire

\begin{tabular}{clcccc}
\hline No & Questions & SA & A & N & D \\
\hline 9. & $\begin{array}{l}\text { In this pandemic situation, I prefer online } \\
\text { learning instead of face-to-face meeting. }\end{array}$ & $50.0 \%$ & $35.0 \%$ & $10.0 \%$ & $5.0 \%$ \\
10. & $\begin{array}{l}\text { I feel difficult to use online learning } \\
\text { application }\end{array}$ & $7.5 \%$ & $24.0 \%$ & $29.5 \%$ & $39.0 \%$ \\
11. & $\begin{array}{l}\text { Online learning is difficult because of the } \\
\text { slow speed internet on my mobile. }\end{array}$ & $47.5 \%$ & $22.5 \%$ & $17.5 \%$ & $12.5 \%$ \\
\hline
\end{tabular}

Furthermore, in this questionnaire there are 4 questions that related to students' English skills. As mentioned before, in this English subject the students not only learn a certain skill but also these four English skills. For reading skill, many students chose neutral (37\%) cannot decide whether or not that online learning engages them in interesting reading skill. Nevertheless, half of the respondents with strongly agree $(17.5 \%)$ and agree $(40.5 \%)$ argued that read online materials through the learning platforms can be a quite interesting experience for them (Mustafa, 2015). The next is listening skill. The highest score is agreed (35\%) however the rest students also chose disagree $(25.5 \%)$. In speaking skill, between neutral $(30 \%)$ and disagree $(32.5 \%)$ is higher than agree $(25 \%)$ and strongly agree $(12.5 \%)$. However, writing skill (SA: $27.5 \%$ and A: $50 \%$ ) got the highest score rather than those three English skills. 
Table 4. Students' Questionnaire

\begin{tabular}{clcccc}
\hline No & \multicolumn{1}{c}{ Questions } & SA & $\mathrm{A}$ & $\mathrm{N}$ & $\mathrm{D}$ \\
\hline 1. & $\begin{array}{l}\text { The use of online learning makes my } \\
\text { reading experience more interesting }\end{array}$ & $17.5 \%$ & $40.5 \%$ & $37 \%$ & $5 \%$ \\
2. & $\begin{array}{l}\text { The use of online learning can improve } \\
\text { my listening skill }\end{array}$ & $10 \%$ & $35 \%$ & $27.5 \%$ & $25.5 \%$ \\
3. & $\begin{array}{l}\text { The use of online learning can improve } \\
\text { my speaking skill }\end{array}$ & $12.5 \%$ & $25 \%$ & $30 \%$ & $32.5 \%$ \\
4. & $\begin{array}{l}\text { The use of online learning makes my } \\
\text { writing experience more interesting }\end{array}$ & $27.5 \%$ & $50 \%$ & $22.5 \%$ & - \\
\hline
\end{tabular}

The next table is about students' favorite online learning application. It can be seen in this table that the top three of these online learning applications are WhatsApp Group (45\%), Google Classroom (25\%), and Schoology (12.5\%). Student D reported his opinion related to this questionnaire. Therefore, the favorite online learning application among students was WhatsApp Group because it took a bit of internet quota and user friendly (Ngalomba, 2020). It can be seen in this transcription:

S.D: Saya memilih WA ya karena nggak habisin banyak kuota internet dari pada aplikasi lainnya. Banyak dosen yang minta kita download Schoology dan aplikasi yang sejenis gitu tapi itu harus bagus internetnya. (I chose WA (WhatsApp Group) because it takes a bit of internet quota rather than others. Some lecturers asked us to download Schoology and etc. but those need good internet connection).

Table 5. students' favourite online learning application

\begin{tabular}{clc}
\hline No & \multicolumn{1}{c}{ Online Learning Applications } & Students' Responses \\
\hline 1. & Edmodo & $7.5 \%$ \\
2. & Schoology & $12.5 \%$ \\
3. & Google Classroom & $25 \%$ \\
4. & Canvas & $6 \%$ \\
5. & Zoom & $3 \%$ \\
6. & Google Meet & $1 \%$ \\
7. & WhatsApp Group & $45 \%$ \\
\hline
\end{tabular}

From the results above, it can be concluded that students give positive response to online learning in this quarantine situation regarding the materials relevancy, convenience, and stimulus in motivating them to learn more about English lesson. On the other hands, the students also have negative responses for online learning. Although they agreed that online learning is effective solution in this pandemic situation, however based on the results of interview the students feel hard to do this activity because their lecturers give so many tasks and this situation forced them to study remotely (Rohman et al., 2020).

This study not only described that online learning is for students in the COVID-19 pandemic but also spotted the availability of internet connection, facilities, and online learning activities implementation. Some students also shared their experiences that they have slowspeed internet connection in their hometown. Therefore, this is very importance to check students' facilities for online learning such as smartphone, personal computer, internet connection, and electricity (Purwanto et al., 2020). Those make them easier for students to participate and listen to their lecturers' explanations in the online teaching and learning process (Purwanto, et al., 2020). It can be seen, from students' favorite online application namely WhatsApp group. Many students chose this application because it takes a bit of internet quota rather than others. Furthermore, these online learning activities decrease the interaction and communication among lecturer and students in teaching and learning processes (Croft, et al., 2010). To avoid misunderstanding in online learning interactions, especially in messaging the text, the lecturer and students used emoticon that provided by online learning applications 
(Dunlap, et al., 2016). The use of emoticons is to represent emotional and personality nuances present in face-to-face communication.

In this case, some students also shared that in the online learning activities they feel bored because it was lack of challenges rather than in face-to-face meeting. This problem caused by the situation that online learning has limited duration in delivering the materials (Butler, 2012). Not all materials can be explained through online learning. It can be seen from the data that students agreed that their reading and writing skills are improved through online learning. Because their assignments were reading some articles and discussed in writing form. For listening, sometimes they just listen to audios and videos given by their lecturer. In speaking skills, they just practice it when presentation time using audio or video. Additionally, based on the interview, some students argued that online learning should be promoted. They think that online learning is quite simple and practical. They mentioned that online learning can be easier because they just typing the assignment and submit it in the form of soft file. On the other hand, some other students emphasize that both online and conventional learning are important. The students also said that face-to-face learning allow them to interact directly with their lecturers. They can ask anything they do not understand and they will get the answer directly. Because it is important for students to obtain response or feedback from their lecturer. However, students also agreed that online learning is a right choice in this pandemic situation.

\section{CONCLUSION}

Regarding the findings of the study, it indicates that students have positive response towards the use of online learning activities in this pandemic situation. The students participated in online learning as a user-friendly learning tool which encourage them to interact with their teachers and peers. Besides, the students also have negative response namely too much homework and inadequate facilities in online learning make them hard to conduct online learning. It is no doubt that students' favorite online application is WhatsApp group. It caused that this application takes a bit of internet quota rather than other applications. As we know that, in this pandemic situation not all students have good internet connection because of some of them live in slow-speed internet connection area. By using technology in online learning can help the students in gaining new vocabularies and four English skills. However, in this case the students shared that their reading and writing are improved rather than their listening and speaking skills because of limited challenges in learning activities. Based on the students' experiences in this study related to online learning in the COVID-19 pandemic, the lecturers should look at the students' condition and situation, availability of internet connection for students, and selection of online learning applications that are effective and efficient for teaching and learning activities. Hopefully, for further studies can involve more participants or different areas that explore about the effectiveness of using online learning in English classroom to face a new normal.

\section{ACKNOWLEDGEMENTS}

We would like to show our gratitude to those who helped us in this research, proof-readers, typists, editor, and the respondents.

\section{REFERENCES}

Archambault, L., Wetzel, K., Foulger, T. S., \& Williams, M. K. (2010). Professional development 2.0: Transforming teacher education pedagogy with 21st century tools. Journal of Digital Learning in Teacher Education, 27 (1), 4-11. https://doi.org/10.1080/21532974.2010.10784651

Butler, K. C. (2012). A model of successful adaptation to online learning for college-bound Native American high school students. Multicultural Education E Technology Journal, 6(2), 60-76. https://doi.org/10.1108/17504971211236245 
Cakrawati, L. M. (2017). Students' perceptions on the use of online learning platforms in EFL classroom. English Language Teaching and Technology Journal, 1(1), 22-30. https:// doi.org/10.17509/elt\%20tech.v1i1.9428

Chakraborty, M., \& Muyia, N. F. (2014). Strengthening student engagement: what do students want in online courses?. European Journal of Training and Development, 38(9), 782-802. https://doi.org/10.1108/EJTD-11-2013-0123

Creswell, J. W. (2012). Educational research: planning, conducting, and evaluating quantitative and qualitative research (4th ed.). Pearson.

Croft, N., Dalton, A., \& Grant, M. (2010). Overcoming isolation in distance learning: Building a learning community through time and space. Journal for Education in the Built Environment, 5(1), 27-64. https://doi.org/10.11120/jebe.2010.05010027

Dunlap, J. C., Bose, D., Lowenthal, P. R., Yorkc, S. C., Atkinson, M., \& Murtagh, J. (2016). What sunshine is to flowers: A literature review on the use of emoticons to support online learning. Emotions, Technology, Design, and Learning, 163-182. https:// doi.org/10.1016/B978-0-12-801856-9.00008-6

European Commission (2001). The e-learning action plan: Designing tomorrow's education. Commission Of The European Communities. https://eurlex.europa.eu/LexUriServ/LexUriServ.do?uri=COM:2001:0172:FIN:EN:PDF

Gillett-Swan, J. (2017). The challenges of online learning: supporting and engaging the isolated learner. Journal of Learning Design, 10(1) 20-30. https:/ / doi.org/10.5204/ild.v9i3.293

Haron, N. N., Yasmin, H.Z., \& Ibrahim, N.A. (2015). E-learning as a platform to learn English among ESL learners: Benefits and barriers. In Mahani, S., \& Haliza, J. (Eds.), Research in Language Teaching and Learning (pp. 79-106). UTM Press.

Hwee, J., Koh, L., \& Chai, C. S. (2016). Teacher professional development for TPACK- 21CL: Effects on teacher ICT integration and student outcomes. Journal of Educational Computing Research, 55(2), 1-25. https:// doi.org/10.1177\%2F0735633116656848

Jasrial, D. (2018). Utilizing WhatsApp application for teaching English language: Why and how?. International Seminar and Annual Meeting BKS-PTN Wilayah Barat Fields of Language, Literature, Arts, and Culture, 1 (1), 151-157.

Kebritchi, M., Lipschuetz, A., \& Santiague, L. (2017). Issues and challenges for teaching successful online courses in higher education: A literature review. Journal of Educational Technology Systems, 46 (1), 4-29. https:// doi.org/10.1177\%2F0047239516661713

Michalos, A. C. (Ed.). (2014). Encyclopedia of quality of life and well-being research. Springer Netherlands. https:// doi.org/10.1007/978-94-007-0753-5

Mustafa, M. B. (2015). One size does not fit all: Students' perceptions about Edmodo at Al Ain University of Science \& Technology. Journal of Studies in Social Sciences, 13(2), 135-160.

Ngalomba, S. (2020, April 23). Using WhatsApp to enhance online learning. University World News. https:/ / www.universityworldnews.com/post.php?story $=20200421102812987$

Okita, S. Y. (2012). Social interactions and learning. In Seel N. M. (Ed.), Encyclopedia of the Sciences of Learning (pp. 182-211). Springer. https://doi.org/10.1007/978-1-4419-1428$\underline{6 \_1770}$

Orlando, J., \& Attard, C. (2016). Digital natives come of age: The reality of today's early career teachers using mobile devices to teach mathematics. Mathematics Education Research Journal, 28 (1), 107-121. https:// doi.org/10.1007/s13394-015-0159-6

Purwanto, A., Pramono, R., Asbari, M., Hyun, C. C., Wijayanti, L. M., Putri, R. S., \& Santoso, P. B. (2020). Studi eksploratif dampak pandemi COVID-19 terhadap proses pembelajaran online di sekolah dasar. EduPsyCouns: Journal of Education, Psychology and Counseling, 2(1), $1-12$.

Ristanti, D. A. (2020, June 11). Memanfaatkan WhatsApp untuk pembelajaran daring pada pandemi. Radar Semarang Digital. https://radarsemarang.jawapos.com/rubrik/untukmuguruku/2020/06/11/memanfaatkan-whatsapp-untuk-pembelajaran-daring-padapandemi/ 
Rohman, M., Marji, Sudjimat,D.A., Sugandi, R.M., \& Nurhadi, D. (2020). Online learning in higher education during COVID-19 pandemic: Students' perceptions. Journal of Talent Development and Excellence, 12 (2s).

Suherdi, D. (2012). Towards the 21st century English teacher education: An Indonesian perspective. Celtic Press.

Wilen-Daugenti, T. (2009). Edu: Technology and learning environments in higher education. Peter Lang.

Zhao, F. (2003). Enhancing the quality of online higher education. Quality Assurance in Education, 11(4), 214-221. https:// doi.org/10.1108/09684880310501395

\section{Author (s):}

* Sari Famularsih (Corresponding Author)

Institute for Research and Community Service,

IAIN Salatiga,

Jl. Lkr. Sel. Salatiga No.KM.02, Kota Salatiga, 50716, Indonesia

Email: sari_famularsih@iainsalatiga.ac.id 